\title{
Effect of Drainage Channels on Vegetation Diversity of Tropical Peatswamp Forest of Sebangau National Park, Indonesia
}

\section{Sosilawaty ${ }^{1 \#}$, Adi Jaya ${ }^{2 * \#}$, Johanna Maria Rotinsulu ${ }^{1}$, Belinda Hastari ${ }^{1}$, Nisfiatul Hidayat ${ }^{1}$, Elipson Sianipar ${ }^{1}$}

${ }^{1}$ Department of Forestry, Faculty of Agriculture, University of Palangka Raya, Indonesia 73112

${ }^{2}$ Department of Agronomy, Faculty of Agriculture, University of Palangka Raya, Indonesia 73112

\#Both authors shared first authorship and corresponding authorship

Received - December 18, 2021; Revision - January 22, 2022; Accepted - February 27, 2022

Available Online - February 28, 2022

DOI: http://dx.doi.org/10.18006/2022.10(1).48.63

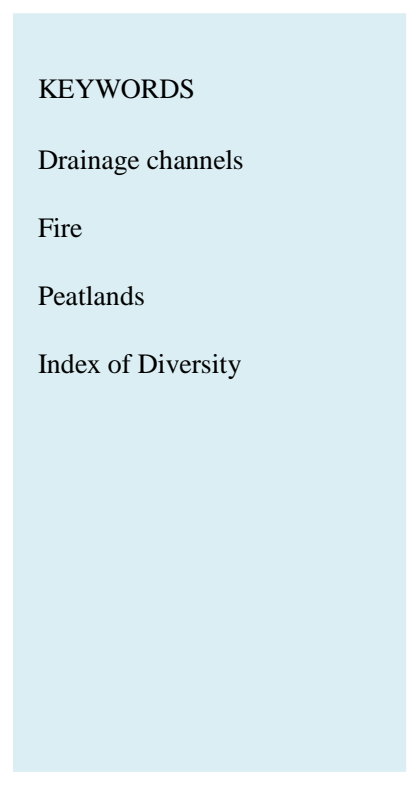

\begin{abstract}
Peat swamp forests are playing important role in climate change by carbon storage, biodiversity conservation, and crucial local livelihoods. The construction of drainage channels in Sebangau National Park, Indonesia negatively affects the Peatland ecosystem and degrades the vegetation diversity. This research aims to study the composition and vegetation diversity of secondary peat swamp forests in Sebangau National Park (SNP), especially around large and small drainage channels. For the observation of vegetation composition and diversity, each observation block consisted of 3 transects that were $300 \mathrm{~m}$ apart from each other, and perpendicular to the channel. For observations on small drainage channel blocks, transects are made to continue the previous transect at a distance of $500 \mathrm{~m}$ from the end of the large drainage channel. On each transect, 5 plots of vegetation were made using the plot line method with a distance of $50 \mathrm{~m}$ between each plot. A total of 15 plots of $30 \mathrm{mx} 30 \mathrm{~m}$ size were prepared for each drainage channel category. Observations were made on the growth rate of seedlings in a $2 \mathrm{~m} \mathrm{x}$ $2 \mathrm{~m}$ plot, poles in a $5 \mathrm{~m} \times 5 \mathrm{~m}$ plot, saplings in a $10 \mathrm{~m} \times 10 \mathrm{~m}$ plot, and trees in a $20 \mathrm{~m} \times 20 \mathrm{~m}$ plot. The results of the study showed that Shorea spp., Combretocarpus rotundatus, Cratoxylum arborencens, and Calophyllum sp. are the dominant plant species of the study area. Overall 92 species were reported from the Large Drainage Channel block and 86 species from the Small Drainage Channel block. Further, the Species Diversity ranged between 1.43 - 1.57 while Species Richness ranged from 16.80 - 23.03, and the
\end{abstract}

* Corresponding author

E-mail: sosilawaty@for.upr.ac.id (Sosilawaty); adijaya@agr.upr.ac.id (Adi Jaya)

Peer review under responsibility of Journal of Experimental Biology and Agricultural Sciences.

Production and Hosting by Horizon Publisher India [HPI] (http://www.horizonpublisherindia.in/).

All rights reserved.
All the articles published by Journal of Experimental Biology and Agricultural Sciences are licensed under a Creative Commons Attribution-NonCommercial 4.0 International License Based on a work at www.jebas.org.

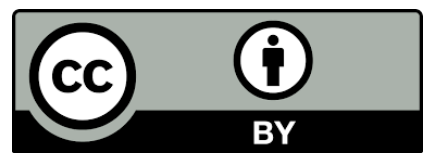


Evenness Index ranged from $0.83-0.92$ at all levels of vegetation growth. Results of the study can be concluded that the channel dimensions do not have any effect on species number, diversity index, species richness, and species evenness at all levels of vegetation growth. The Similarity Index of species at seedlings, saplings, and poles is more than $50 \%$, while at the tree level it was reported less than $50 \%$.

\section{Introduction}

Peatland ecosystems are always associated with water-saturated conditions, high organic matter, and flooded anaerobic conditions The peatland ecosystem is of global importance because of its high carbon storage, role in global climate change, higher biodiversity, and importance in community livelihoods (Joosten 2015; Wildayana 2017). Parish et al. (2008) suggested that tropical peatland covers one-third of global wetlands, and occupied the area of 440,000 to $600,000 \mathrm{~km}^{2}$. From the total tropical peatland area, the maximum areas are distributed in Southeast Asia, South America, and Africa's Congo Basin (Page et al. 2011; Gumbricht et al. 2017). Further, it has the most diverse and most threatened peatland environment and is associated with significant carbon emissions by natural decomposition, fires, and biodiversity loss (Page et al. 2006; Yule 2010; Turetsky et al. 2015). In Southeast Asia, particularly in Malaysia, Sumatra, and Kalimantan, peat forest cover has declined from $119,000 \mathrm{~km}^{2}$ to $46,000 \mathrm{~km}^{2}$ from 1990 to 2015 , while agricultural areas on peatland increased from $17,000 \mathrm{~km}^{2}$ to $78,000 \mathrm{~km}^{2}$ during the same study period (Miettinen et al. 2016). Small-scale farmers, industrial oil palm, and expansion of paper pulp are some responsible factors for this agricultural conversion which put this peatland agricultural system is in danger of extinction (Miettinen et al. 2016; Wijedasa et al. 2018; Tan et al. 2021).

Peat swamp forest has very high biodiversity and is a habitat for various flora and fauna including 1,524 plant species, 123 mammals, 268 birds, 75 reptiles, 27 amphibians, and 219 fish species (Page et al. 1997; Yule 2010; Posa et al. 2011; Posa et al. 2011). Along with this, PSF is also an important ecosystem for the primates Pongo spp., clouded leopard (Neofelis diardi) and cat species, Storm stork (Ciconia stormi), white-winged duck (Asarcornis scutulata) (Silvius \& Verheugt 1986; MorroghBernard et al. 2003; Cheyne et al. 2011; Cheyne et al. 2014).

Thus, national and international efforts have been needed to be enhanced for conserving the remaining peat swamp forest (PSF). Some of the important challenges which affect efforts to restore degraded peatlands are increasing the groundwater level on drained peatlands and the development of economically competitive crop species suitable for paludiculture (Wosten et al. 2008; Wichtmann et al. 2010; Uda et al. 2017; Uda et al. 2017; Evans et al. 2019; Tan et al. 2021). Damage to the peat ecosystem causes disturbance to this diversity (Mishra et al. 2021). Tropical peatland degradation generally begins after converting PSF into a nonforest area for agriculture, smallholder plantations, and industrial forest plantations, which is usually accompanied by drainage channel construction. Changes in land use from PSF to open peat cause serious damage to the ecological function of the peat as a carbon sink and store, in addition to biodiversity. The decrease in forest cover, mainly due to drainage, is also associated with a decrease in the groundwater level, which impact the characteristics of peat soils including the processes of decomposition and compaction that result in an increase in bulk density (Wösten et al. 2006a; Sherwood et al. 2013; Sumargana et al. 2016; Uda et al. 2017; Cooper et al. 2019a; Evans et al. 2019; Sinclair et al. 2020). Bulk density of peat soil is important in regulating the hydrology of peatlands by influencing groundwater storage capacity (Rydin and Jeglum 2015), and reducing the hydraulic conductivity of peat (Päivänen 1973), water retention, and increasing flooding (Hooijer et al. 2012; Könönen et al. 2015; Evers et al. 2017; Evans et al. 2019). The change from PSF to other uses that reduce land cover also changes hydrological functions, especially surface runoff. Anshari et al. (2010) reported that conversion of PSF to open areas by removing vegetation and drainage reduced the $\mathrm{C} / \mathrm{N}$ ratio, organic acid, and peat soil compaction and increased bulk density and $\mathrm{pH}$ of peat soil as a direct result of drainage. Thus, changes in the physical and chemical characteristics of peatlands tend to cause changes in the vegetation structure and composition of peatlands, but empirical studies to investigate the effect of changes in the properties of these peat soils are still limited, especially in tropical peat.

Sebangau forest of Kalimantan, Indonesia, have diverse biodiversity and have more than 215 tree species, 92 non-tree plant species, 73 ant species, 66 butterfly species, 297 spider species, 41 Komodo dragon/damselfly species, 55 fish species, 11 species of amphibians, 46 species of reptiles, 172 species of birds, and 65 species of mammals (Husson et al. 2018). Sebangau National Park (SNP) is one of the Indonesian PSF ecosystems which has relatively good conditions in carbon storage and water regulation as compared to the surrounding area. Therefore, it is necessary to manage it wisely and sustainably because SNP's peat swamps are believed to have high economic and ecological value (Taman Nasional Sebangau, 2011; Khalwani et al. 2017). Resort Mangkok or commonly called SSI (former HPH PT, Sinatra Sebangau Indah), is included in the working area of the National Park 
Management Section, Sebangau II, Pulang Pisau Regency. From the 1970s until the mid-1990s, various illegal logging activities were rampantly carried out by people in the Sebangau area. Along with this, the research area was faced forest fires during the long dry season of 1992, 1994, 1997, and 2002. In the early 1970s, the Sebangau River is one of the important transportation routes which mainly used for timber transportation. These activities cause the Sebangau peat-swamp forest area to lose water and damage the hydrological function of the area, causing drought and flammability in the dry season (Taman Nasional Sebangau, 2016).

In general, the PSF ecosystem is easily disturbed, and once it is disturbed it will be difficult to return to its original state. Excessive drainage and fires in the Mangkok Resort area of Sebangau National Park peat swamp ecosystems are likely to cause changes in the structure of the vegetation that grows in these localities. This may also influence the properties of peat soil due to excess drainage which has implications for vegetation growth. Thus, changes in the physical and chemical characteristics of the peatlands will most likely cause changes in the structure and composition of the vegetation of this area. Further, changes in land use from PSF to open peat which is usually associated with drainage seriously damage the various ecological functions including biodiversity (Wösten et al. 2006b; Sumargana et al. 2016; Uda et al. 2017; Cooper et al. 2019b). Furthermore, it has also an impact on the characteristics of peat soil, including the process of decomposition and compaction (Sherwood et al. 2013; Evans et al. 2019; Sinclair et al. 2020).

The expected recovery is a restoration that leads to the original ecosystem, although this is very difficult and takes a very long time, especially with continued disturbances in the ecosystem (Kimmins 1997). The progress of the recovery process can be measured by several factors, one of which is by looking at the composition of the type and structure of the vegetation in the area. This research was conducted to evaluate the effect of large drainage channels and small drainage channels on the plant composition and diversity due to changes in hydrological function in the peat swamp forests.

\section{Materials and Methods}

The current study was carried out in the area of Mangkok Resort, Sebangau NP, Central Kalimantan, Indonesia (Figure 1). Field observations and data collections were carried out in 2018. Geographically SNP is located at $1^{\circ} 54^{\prime}-3^{\circ} 08^{\prime}$ South Latitude and $113^{\circ} 20^{\prime}-114^{\circ} 03^{\prime}$ East Longitude. Further, the study area is located between the 3 regencies/cities namely Palangka Raya City, Katingan Regency, and Pulang Pisau Regency. The topography consists of coastal lowlands with altitudes ranging from 2 to 8 MSL and it is generally a waterlogged wetland area (swamp). The park is covered by deep peat with a thickness of more than $3 \mathrm{~m}$, the study area is also suffered by repeated fire in different areas since 1997, and includes former concession and illegal logging areas with small drainage channels constructed. In the Mangkok Resort research area, water channels were previously used for logging and transporting. This area of about 88 ha and is allocated by SNP for research-based tourism development, including biodiversity research, peatland restoration, and social communities. Various efforts including the construction of 45 canal blocks/dams have been carried out for rehabilitation. The constructed dams have been divided into 3 categories including 10 permanent, 9 semipermanent, and 26 simple dams (Taman Nasional Sebangau 2016). Hydrological rehabilitation was carried out by constructing large channel blocks in 2006 and small channel block in 2016 (Balai Taman Nasional 2015).

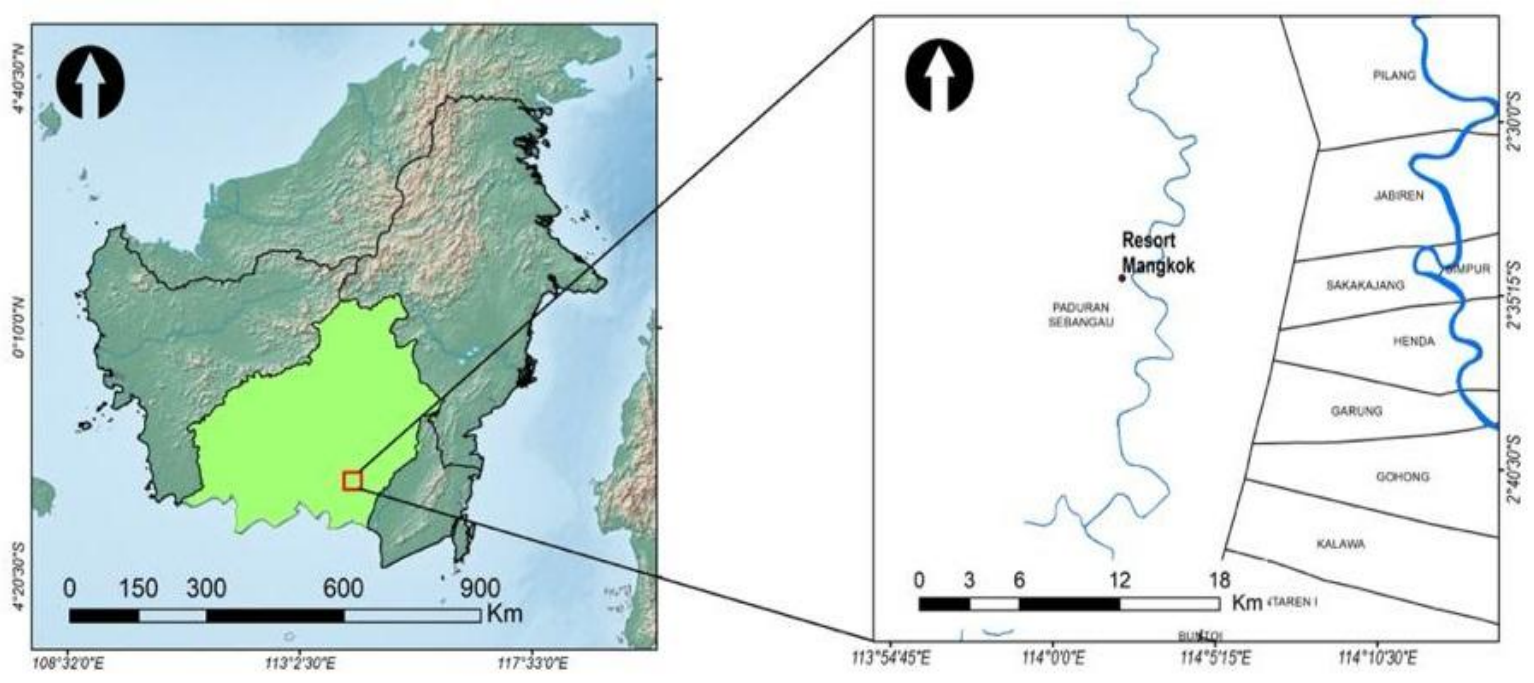

Figure 1 Research location at Sebangau National Park, Central Kalimantan, Indonesia

Journal of Experimental Biology and Agricultural Sciences http://www.jebas.org 


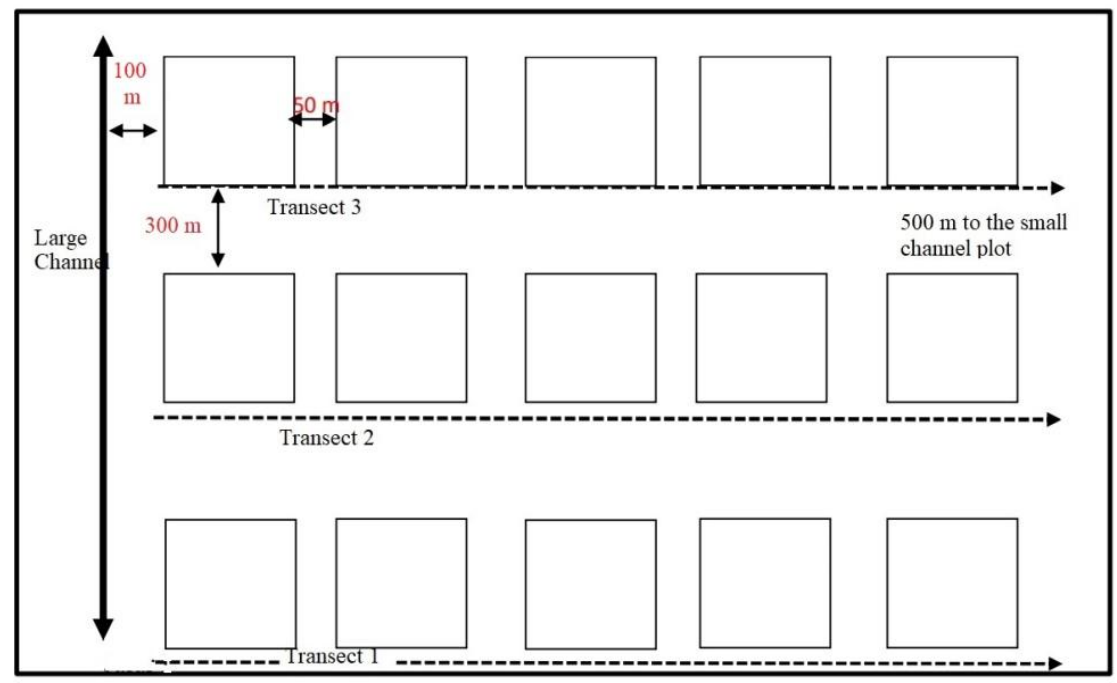

Figure 2 Research Plot Placement Design

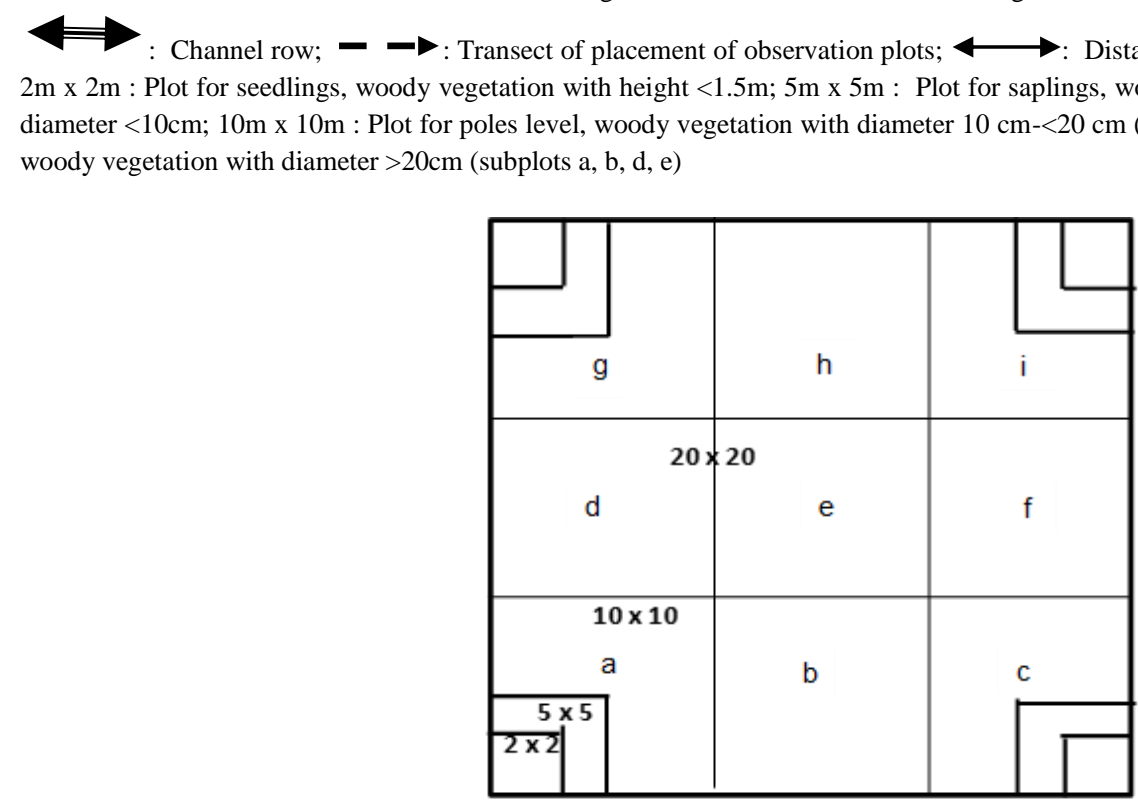

Figure 3 Plot design for Vegetation Measurement

Various observations related to the vegetation diversity including seedlings, saplings, poles, and trees were undertaken from the large and small drainage channels area of Resort Mangkok, National Park of Sebangau. Path design, vegetation category size definitions, and plot placement are shown in Figures 2 and 3.

Observation blocks in the study area are located on 2 drainage channels located at Mangkok Resort: the large drainage channel was $>10 \mathrm{~m}$ wide while the small drainage channel was $2.5 \mathrm{~m}$ wide. Vegetation observation blocks were placed systematically near to each channel. Each block was made up of 3 transects separated from each other by $300 \mathrm{~m}$ and located at a distance of $50 \mathrm{~m}$ from the channel. In each transect, 5 vegetation plots were made using the plot line method (Kusmana 1997). The observation transect on the large channel begins at a distance of 100 meters, perpendicular to the channel. While the small channel transect starts at a distance of about $1000 \mathrm{~m}$ from the large channel. Thus, the distance between the end of the large channel observation transect and the beginning of the small channel transect is about 500 meters. The dimensions of the plot was $30 \mathrm{~m} \times 30 \mathrm{~m}$ and the total number of plots was 30 (15 for each drainage channel size category). Observations were made on the growth rate of seedlings in a $2 \mathrm{~m} \times 2 \mathrm{~m}$ plot, poles in a $5 \mathrm{~m}$ x $5 \mathrm{~m}$ plot, saplings in a $10 \mathrm{~m} \times 10 \mathrm{~m}$ plot, and trees in a $20 \mathrm{~m} \mathrm{x}$ $20 \mathrm{~m}$ plot Overall, the sample plot area in each research block was 1.35 hectares. 


\subsection{Data Collection and Analysis}

The biodiversity index of species for each plot was calculated using standard parameters including importance value index (IVI), species diversity index, species richness index, species evenness index, and species similarity index (Table 1). Data from vegetation inventory are analyzed to determine the composition and dominance of the species. The dominance of a species will be indicated by the importance value index. Plant density indexed (INP) for pole and tree-level vegetation is the sum of Relative Density (RD), Relative Frequency (RF), and Relative Dominance (RD), while for seedling and sapling level vegetation, the INP value is calculated by the sum of RD + RF (Indriyanto 2006). For the species diversity index, we used the calculation of the Shannon - Wiener Index (Magurran 2004), while for the calculation of the species richness index Margalef Index was used (Margalef 1958). Pielou's evenness index $\left(E_{\text {Pielou}}\right)$ (Magurran 2004) was used for species evenness index, while for the species similarity index Kent's (2011) method was used.

Table 1 Equations for calculating index diversity of species

\begin{tabular}{|c|c|c|c|}
\hline Index & Equation & Description & References \\
\hline $\begin{array}{l}\text { Important value } \\
\text { index }\end{array}$ & $\begin{array}{c}\text { Relative Density }+\begin{array}{c}\text { Relative Frequency }+ \text { Relative } \\
\text { dominance }\end{array}\end{array}$ & & Indriyanto 2006 \\
\hline Relative & The density of a species & & \\
\hline Density & $\overline{\text { Total Density of all species }} \times 100$ & & \\
\hline \multirow{2}{*}{ Species Density } & Number of a species & & \\
\hline & $\overline{\text { Total Area Sampled }}$ & & \\
\hline \multirow{2}{*}{$\begin{array}{l}\text { Relative } \\
\text { Frequency }\end{array}$} & Area of plot in which species occur & & \\
\hline & $\begin{array}{c}\text { Total Area Sampled } \\
\end{array}$ & & \\
\hline \multirow{2}{*}{$\begin{array}{l}\text { Frequency of } \\
\text { Species }\end{array}$} & Area of plot in which species occur & & \\
\hline & $\begin{array}{c}\text { Total Area Sampled } \\
\end{array}$ & & \\
\hline \multirow{2}{*}{$\begin{array}{c}\text { Relative } \\
\text { Dominance }\end{array}$} & Dominance of a species & & \\
\hline & Total Dominance of all species $\times 100$ & & \\
\hline \multirow{2}{*}{$\begin{array}{l}\text { Dominance of } \\
\text { species }\end{array}$} & Total basal area of a species & & \\
\hline & Total Area Sampled. & & \\
\hline $\begin{array}{c}\text { Index of } \\
\text { Species } \\
\text { Diversity (H') }\end{array}$ & $\begin{array}{l}\qquad \mathrm{H}^{\prime}=-\sum_{i=1}^{s}\left(\frac{\mathrm{ni}}{\mathrm{N}}\right) \ln \left(\frac{\mathrm{ni}}{\mathrm{N}}\right) \\
\mathrm{H}^{\prime}=\text { Shannon }- \text { Wiener Index } \\
\mathrm{ni}=\text { Number of individuals species } \\
\mathrm{N}=\text { Total number of individuals }\end{array}$ & $\begin{array}{l}\text { The magnitude of the Shannon- } \\
\text { Wiener species diversity index is as } \\
\text { follows: } \\
\text { a. } \mathrm{H}^{\prime}>3 \text {, species diversity is } \\
\text { abundant with a high number of } \\
\text { individual wealth. } \\
\text { b. } \mathrm{H}^{\prime} 1 \leq \mathrm{H}^{\prime} \leq 3 \text {, species diversity is } \\
\text { moderate. } \\
\text { c. } \mathrm{H}^{\prime}<1 \text { indicates that the diversity } \\
\text { of species is low or low }\end{array}$ & Magurran 2004 \\
\hline $\begin{array}{c}\text { Index of } \\
\text { Species } \\
\text { Richness (R) }\end{array}$ & $\begin{array}{l}\qquad \text { Dmg }=\frac{S-1}{\ln N} \\
\text { Dmg = Margalef's Index } \\
\mathrm{S}=\text { Number of species observed } \\
\mathrm{N}=\text { Total number of individuals of all species in the sample } \\
\mathrm{Ln}=\text { Natural logarithm }\end{array}$ & $\begin{array}{l}\text { Margalef's index }(\mathrm{R}) \text { criteria are: } \\
\text { a. } \mathrm{R}<3.5 \text {; low density } \\
\text { b. } 3.5<\mathrm{R}<5.0 \text {; medium density } \\
\text { c. } \mathrm{R}>5.0 \text {; high density }\end{array}$ & Margalef 1958 \\
\hline $\begin{array}{c}\text { Index of } \\
\text { Species } \\
\text { Evenness (E) }\end{array}$ & $\begin{array}{l}\qquad \mathrm{E}=\frac{\mathrm{H}^{\prime}}{\ln \mathrm{S}} \\
\mathrm{E}=\text { Index of Species Evenness }(0-1) \\
\mathrm{H}^{\prime}=\text { Shannon_Wiener Index } \\
\mathrm{S}=\text { Number of Species }\end{array}$ & $\begin{array}{l}\text { The evenness index ranges between } \\
0 \text { and } 1 ; 0 \text { indicates that the evenness } \\
\text { level is very uneven; whereas if the } \\
\text { value is close to } 1 \text {, almost all species } \\
\text { that exist, have the same abundance } \\
\text { (Magurran, 2004) }\end{array}$ & Magurran 2004 \\
\hline $\begin{array}{l}\text { Similarity Index } \\
\text { (SI) }\end{array}$ & $\begin{array}{l}\qquad \text { SI }=\frac{2 C}{(A+B)} \\
\text { SI= Sorenson Similarity Index } \\
A=\text { Number of species from sample A } \\
B=\text { Number of species from sample B } \\
C=\text { Number of similar species in both samples A and B }\end{array}$ & $\begin{array}{l}\text { SI }>50 \text { means the area has the same } \\
\text { species in the community; SI }<50 \% \text {, } \\
\text { then there are differences in the } \\
\text { types of community constituents in } \\
\text { the area or do not even have the } \\
\text { same types. }\end{array}$ & Kent, 2011 \\
\hline
\end{tabular}




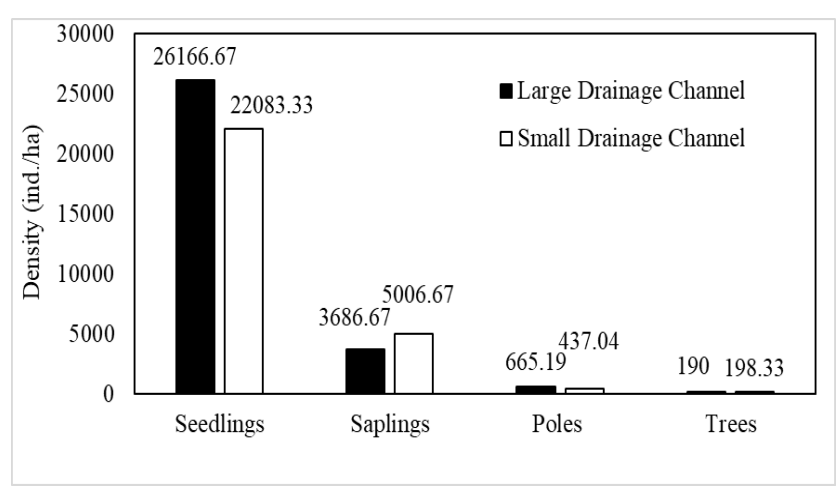

(a)

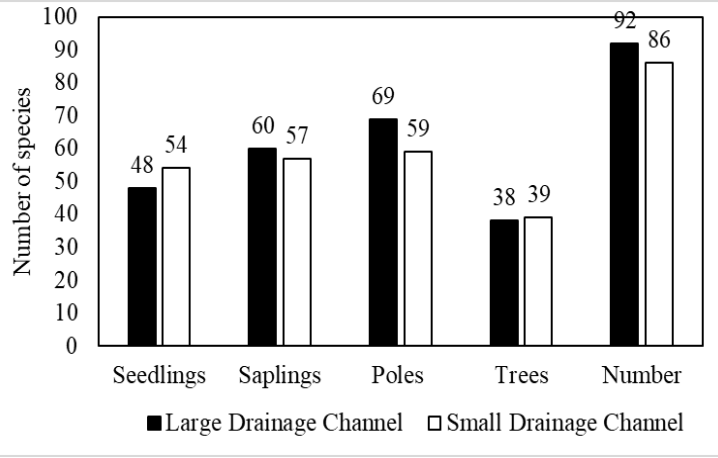

(b)

Figure 4 (a) Density and (b) Number of Species at all Growth Level

\section{Results and Discussion}

\subsection{Species Composition and Dominance}

Total 112 tree species have been reported from the vegetation analysis near the large and small channel blocks observation of Sebangau. The number of species reported from the large drainage channel blocks was not different from the reported from the small drainage channel (Figure 4). Around the large channel block, there were a total of 92 species, consisting of 48 seedlings, 60 saplings, 69 poles, and 38 adult tree species (Annexure 1). Meanwhile, around the small drainage block, there were a total of 86 species, consisting of 54 seedlings, 57 saplings, 59 poles, and 39 adult tree species. The conditions in these 2 blocks with a decrease in vegetation density with a pattern like a letter "J" upside down (Figure 4a), indicated that the stand structure was still normal and the regeneration process was running well. Based on the density values of the 2 studied blocks the pattern is as seedlings > saplings $>$ poles $>$ trees. These results are in line with several previous researchers Indriyanto (2006), Sidiyasa (2009), and Hidayat (2014) who reported similar regeneration processes. Competition for space utilization, soil nutrients, and sunlight causes the normal pattern of the regeneration process. In addition to the influence of environmental factors, it turns out that changes in vegetation density are influenced by growth and deaths (Indriyanto 2006), which leads to a reduction in the number of surviving individuals at each growth stage (Kusmana and Susanti 2015). One of the indicators of forest restoration is the creation of natural regeneration, which is marked by the growth of natural regeneration and the resilience of species diversity. However, not every species can regenerate because it is possible to change the dominant species at each growth stage.

In the case of types of species, a wide variation was reported between the studied drainage channel blocks, and the species found in large drainage channel block are not reported from the small drainage channel block. The major species reported from the large drainage channel block are Aglaia sp. (Bangkuang Napu), Alstonia spatulata (Pulai), and Anisoptera sp. (Katimpun), while Ardisia sp. (Kayu Bulu), Artabotrys suaveolens, Blumeodendron kurzii (kenari) are the major species which found in small drainage channel blocks. Furthermore, tree species that are always reported from the large channel are Calophyllum inophyllum (Kapur naga), Calophyllum nodusum (Kakal), Calophyllum soullatri (Takal), Calophyllum sp. (Panaga jangkar).

In general, the species composition obtained from this study was not so much different than the other studies in different locations of SNP. Similarly, the number of species reported from the PSF block ranged from 100 to 113 species (Page et al. 1999; Mirmanto 2010; Nugroho 2011; Siahaan et al. 2014). Furthermore, Nugroho (2011) suggested that among the studied species the dominant species was Palaquium leiocarpum Boerl.v. The findings of Kalima and Denny (2019) and Qirom et al. (2019) are slightly different from the present study and they reported fewer species ranging from 47 - 96 species from the different locations of SNP. Furthermore, the composition and types of species outside SNP are also very diverse; Astiani (2016) stated that the results of research on degraded PSF in Riam Berasap, West Kalimantan and found 108 species from the three types of land cover namely $>10$ years after logging (low), 5-10 years after felling (medium), and degraded forest (open area or former fire). This variation in the number of species shows that PSF species composition is very dynamic, and these species variations are related to the location and time of observations. Similar types of diversity in species compositions were reported by Page et al. (1999), Mirmanto (2010), and Mofu (2011). Page et al. (1999) found that in PSF habitat sub-types peat depth increases towards the center of the Sebangau peat dome.

The absence of a significant difference in the number of species between the Large Channel Block and the Small Channel Block indicates that the channel size does not affect the number and types of the vegetation. So far there has been no publication that directly relates the dimensions of the canal to the groundwater level on peatlands, but the water level in the canal and the distance from the 
Table 2 Dominant Species along with the Large and Small Drainage Channels

\begin{tabular}{|c|c|c|c|c|}
\hline Observation Block & Growth Level & Local Name & Latin Name & IVI $(\%)$ \\
\hline \multirow{12}{*}{ Large Drainage Channel } & \multirow{3}{*}{ Seedlings } & Tatumbu & Syzygium havilandii & 17.74 \\
\hline & & Gerunggang & Cratoxylum arborescens & 16.86 \\
\hline & & Tatkal & Callophyllum soullatri & 13.45 \\
\hline & \multirow{3}{*}{ Saplings } & Kemuning & Xanthophyll eurhynchum & 15.09 \\
\hline & & Malam-Malam & Dyospyros bantamensis & 13.68 \\
\hline & & Gentalang & Palaquium $s p$. & 11.85 \\
\hline & \multirow{3}{*}{ Poles } & Gerunggang & Cratoxylum arborescens & 44.17 \\
\hline & & Belangeran & Shorea balangeran & 14.81 \\
\hline & & Trending & Campnosperma coriaceum & 13.21 \\
\hline & \multirow{3}{*}{ Trees } & Belangeran & Shorea balangeran & 33.25 \\
\hline & & Rahanjang & Xylopia fusca & 24.47 \\
\hline & & Gerunggang & Cratoxylum arborescens & 18.66 \\
\hline \multirow{12}{*}{ Small Drainage Channel } & \multirow{3}{*}{ Seedlings } & Kemuning & Xanthophyll eurhynchum & 26.72 \\
\hline & & Jambu Hutan & Syzygium sp. & 23.98 \\
\hline & & Jambu-Jambu & Syzygium incarnatum & 15.37 \\
\hline & \multirow{3}{*}{ Saplings } & Kemuning & Xanthophyll eurhynchum & 22.53 \\
\hline & & Jambu Hutan & Syzygium sp. & 20.38 \\
\hline & & Belangeran & Shorea balangeran & 10.16 \\
\hline & \multirow{3}{*}{ Poles } & Belangeran & Shorea balangeran & 29.88 \\
\hline & & Malam-Malam & Dyospyros bantamensis & 18.31 \\
\hline & & Manggis Hutan & Garcinia banana & 18.22 \\
\hline & \multirow{3}{*}{ Trees } & Malam-Malam & Dyospyros bantamensis & 28.57 \\
\hline & & Belangeran & Shorea balangeran & 28.30 \\
\hline & & Tumih & Combretocarpus rotundatus & 25.55 \\
\hline
\end{tabular}

canal significantly change the characteristics of peat, especially bulk density (Astiani et al. 2017; Sinclair et al. 2020). The results of the study showed that drainage ditches in peatland landscapes lowered the water level more than 3 times, and it reached from $11.7 \mathrm{~cm}$ to $37.3 \mathrm{~cm}$. The impact of this drainage channel on the water level is worse in dry months (July-August). The lowering of the peat water level makes changes the microclimate of the soil, especially the temperature and water content of the peat. Astiani et al. (2017) also reported that changes in land use on peat along with drainage development also affected the peat water level.

As shown in Table 2 dominance of the species is described by the IVI value of standing vegetation. The upright vegetation in the study area was dominated by Shorea balangeran (Balangeran) which were present at almost all growth levels of both studied blocks. Further, S. balangeran is a commercial species that is almost extinct in its natural habitats (Wardani and Susilo 2016) and can be categorized as a species that is resistant to growth and regeneration in burned forests (Atmoko 2011). In addition, this tree species cannot tolerate shaded conditions and it required light for its normal growth and that's why it is well acceptable under the studied environmental conditions (Wibisono et al. 2005). Species dominance also came from pioneer species, such as Combretocarpus rotundatus, Cratoxylum arborescence, and Calophyllum sp. and this indicates that this location is highly disturbed by drainage, fire, or waterlogging. In peatlands affected by fires, species from the genus Calophyllum are generally found, and the species such as $C$. rotundatus, Palaquium sp., and $C$. arborencens were reported from the studied areas also (Astiani 2016; Simbolon 2004; Yulianti et al. 2009). The channel of the study area causes excessive drainage, which results in repeated droughts and fires in the Mangkok Resort area. The results of the current study suggest that repeated fires made changes in vegetation composition and disrupt natural regeneration processes. 
The findings of Hoscilo et al. (2011) also suggested that repeated fires causes land cover changes and mostly it is dominated by nontimber vegetation such as ferns or tree mosaics.

\subsection{Species Diversity Index (H')}

The species diversity index is a parameter that can describe the state of succession or community stability (Goodman 1975; Subiandono and Heriyanto 2016; Pamoengkas et al. 2019). Further, a community can keep itself stable, despite disturbances to its components. Kalima and Denny (2019) stated that forest communities consist of various types of plants, the older the forest stand, the species diversity becomes higher. The diversity index values for each growth stage at the large drainage channel block and small drainage channel block are presented in Figure 5. All values of the species diversity index $\left(\mathrm{H}^{\prime}\right)$ at various growth stages fall between 1.43 and 1.57, which means the species are abundant and well distributed. The results of the calculation of the diversity index also show that the size of the drainage channel does not affect the value of the species diversity index, although the highest $\mathrm{H}^{\prime}$ value was observed for the large drainage channel block (1.461.57) but it was lower than the peat swamp forest area of Sumatra, which ranges from 2.89-2.96 (Istomo and Aziz 2021).

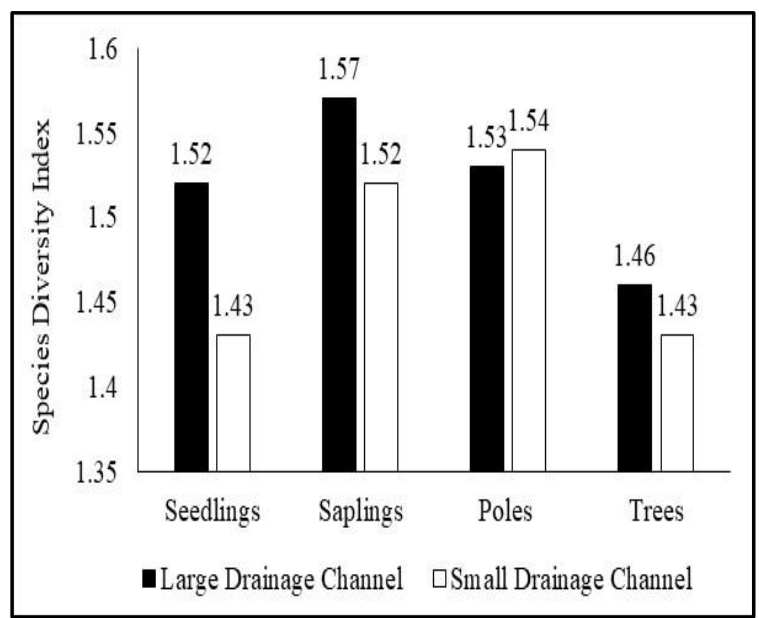

Figure 5 Index of Species Diversity at all Growth Level for both types of channel

\subsection{Species Richness Index (R)}

Ismaini et al. (2015) stated that species richness is the number of species in a community, where a larger number of species found have the highest species richness index. The Margalef richness index divides the number of species by natural functions, showing that an increase in the number of species is inversely proportional to an increase in the number of individuals. According to Magurran (2004), an R-value <3.5 indicates low species richness, while a value of 3.5 to 5 indicates moderate species richness, and an R-value > 5 indicates high species richness. The species richness index in the large drainage channel block is in the range of $16.80-23.03$ while it was reported 18.31- 20.93 for the small drainage channel (Figure 6). The highest species richness value 23.03 was at the poles growth stage of the large drainage channel. The species richness index of the Sebangau research area is higher than other research sites of the peat swamp forest area of Sumatra where it was reported between 5.18-6.51 (Istomo and Aziz 2021).

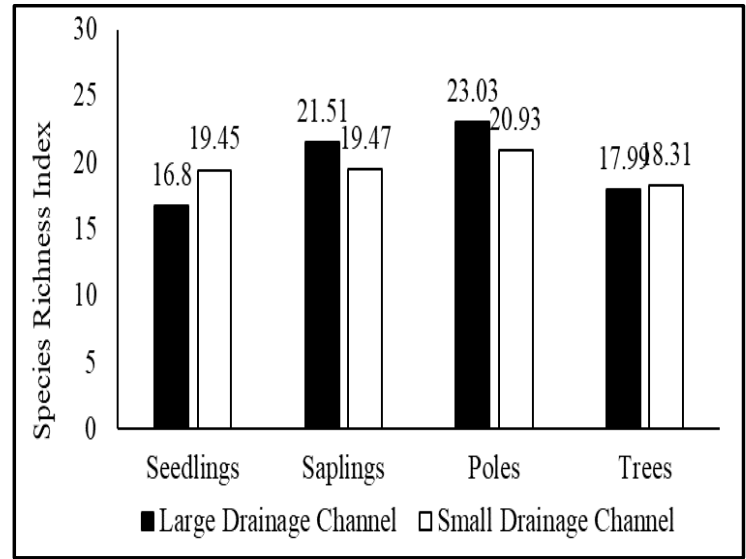

Figure 6 Index of Species Richness at all Growth Level

\subsection{Species Evenness Index (E)}

The evenness index value is used to measure the degree of evenness of the abundance of individual species in the community. It describes the balance between one community to another. It is stated that if the value of $\mathrm{E}$ is close to 1 , the evenness is high (Soegianto 1994; Sidauruk 2016). According to Kusnadi (2015), the highest evenness index is directly proportional to the species diversity index. According to Magurran (2004), if an evenness value is close to 1 indicates that a community is more evenly distributed, whereas it is increasingly unevenly distributed if the value is close to zero. The evenness index value is strongly influenced by the diversity index and the number of species. The evenness index is directly proportional to the species diversity

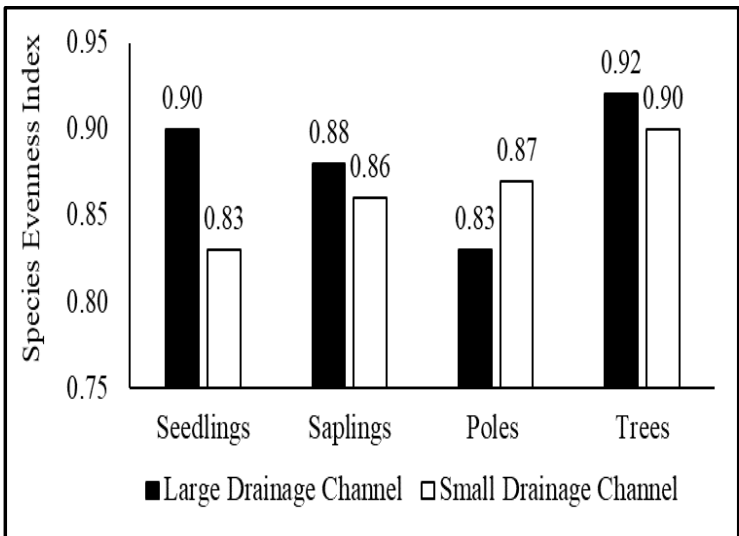

Figure 7 Index of Species Evenness at all Growth Level 
index, the higher diversity index values also have the higher evenness index values (Odum 1993). Further, if the species diversity index is low and the number of species is also low the evenness index value will be also small.

As shown in Figure 7, the Evenness Index (E) of the two studied blocks is high with a value range of $0.83-0.92$ at various growths stages; and this was slightly higher compared to Gunawan et al. (2012), where the E value was reported between 0.77 and 0.84 . The highest values were found for adult trees near both large and small drainage channel which suggest that these are the species with a relatively equal and even number of individuals. Further, the species evenness index for both the studied block was very high which suggested that species are evenly distributed in both the studied blocks. This is also suggested that the channel size has no significant effect on the resulting evenness index value.

\subsection{Species Similarity Index (SI)}

Results related to the similarity values for all growth levels have been given in Table 3, which suggests that the similarity values between large and small channel blocks are in the range of 46.75 $73.44 \%$. The similarity of species was shown at the various growth stages of seedlings, saplings, and poles with SI values $>50 \%$, while in the case of adult trees SI value was reported $46.75 \%$ which showed higher dissimilarity. Djufri (2003) suggests that if the SI value is greate 0072 than $75 \%$ the similarity criterion is very high, while when it is in the range of $50-75 \%, 25-50 \%$, and $<$ $25 \%$ it comes under the categories of high similarity, low similarity, and very low similarity respectively. Many tree species are that are present in the large channel are not found in the small channel and vice versa. This phenomenon occurs because the forest conditions are relatively nonhomogeneous. Barbour et al. (1987) suggested that individuals of the same type will occupy relatively homogeneous microsite conditions because these species naturally have developed adaptation and tolerance mechanisms to their habitat. Loveless (1983) also suggested that physical and chemical factors along with animals and humans' activities also determined the types of plant or plant community.

According to the Taman Nasional Sebangau (2016) reports, the forest fire is more common around the large channel and this might be responsible for the smaller value of the similarity index Further, variations in environmental, physical, and chemical conditions and the interactions between the study area species also affect the similarity index, and as a result study area also had low category vegetation similarity (Loveless 1983). Barbour et al. (1987) suggested that individuals of the same type occupy relatively homogeneous microsite conditions and this helps species to naturally developed adaptation and tolerance mechanisms for their habitat.

\section{Conclusion}

The channels were constructed as part of a previous logging concession in the PSF area of Mangkok Resort, SNP. Results of the study suggested that although the construction of channels resulted in the over-drainage which developed the dry conditions and increased the chances of forest fires but after this also vegetation composition did not show any significant changes in the study area. Further, in terms of variations in distance from the river and peat depth, the number of species recorded in this study is higher than the previous studies in the same location, but it is not so much different from the studies conducted in other locations of SNP. Study area vegetation is dominated by Shorea spp, $C$. rotundatus, C. arborencens, and Calophyllum sp. Results of the study also suggested that the dimensions of the drainage channel seem did not affect the number of species, species diversity index, species richness index, and evenness index. Further to better establish the influence of the existence of channels on the composition and diversity of vegetation types in SNP and other degraded PSF areas the consistency can be tested by making observation blocks on the channel that have been recently rehabilitated.

\section{Acknowledgment}

The authors would like to express the highest appreciation to the ICRAF research project, which has funded this research. Also, the authors would like to thank Dr. Subekti Rahayu as Senior Research, Biodiversity \& Carbon Specialist, Mrs. Endri Martini, S.Hut., M.Sc., and Mr. Sidiq Pambudi S.Si., as field supervisors and data processing. The author would also like to thank the Sebangau NP Management, particularly the Head and Staff of

Table 3 Species Similarity Index (SI \%) at Observation Block

\begin{tabular}{|ccccc|c|}
\hline \multirow{2}{*}{ Growth stage } & \multicolumn{3}{c|}{ Number of Species } & Number of Species found in both blocks & SI (\%) \\
& Large Drainage Channel & Small Drainage Channel & 31 & 60.78 \\
\hline Seedlings & 48 & 54 & 41 & 70.09 \\
\hline Saplings & 60 & 57 & 59 & 18 & 73.44 \\
\hline Poles & 69 & 39 & 46.75 \\
\hline Trees & 38 & 59 & 47 & 40 \\
\hline
\end{tabular}

Journal of Experimental Biology and Agricultural Sciences http://www.jebas.org 
Mangkok Resort, who have facilitated and assisted the data collection process in the field. Also, to the Chancellor of the University of Palangka Raya (UPR), the Dean of the UPR Faculty of Agriculture, and the Department of Forestry, UPR, who have supported this research.

\section{References}

Anshari, G. Z., Afifudin, M., Nuriman, M., Gusmayanti, E., Arianie, L., Susana, R., \& Rafiastanto, A. (2010). Drainage and land use impacts on changes in selected peat properties and peat degradation in West Kalimantan Province, Indonesia. Biogeosciences, 7(11), 3403-3419.https://doi.org/10.5194/bg-73403-2010.

Astiani, D. (2016). Tropical peatland tree-species diversity altered by forest degradation. Biodiversitas Journal of Biological Diversity, 17(1):102-109. https://doi.org/10.13057/biodiv/d170115.

Astiani, D., Burhanuddin, B., Curran, L. M., Mujiman, M., \& Salim, R. (2017). Effects of drainage ditches on water table level, soil conditions and tree growth of degraded peatland forests in West Kalimantan. Indonesian Journal of Forestry Research, 4(1), 15-25.

Atmoko, T. (2011). Potensi regenerasi dan penyebaran Shorea balangeran (korth.) Burck di sumber benih Saka Kajang, Kalimantan Tengah. Jurnal Penelitian Ekosistem Dipterokarpa, 5(2), 21-36.https://doi.org/10.20886/jped.2011.5.2.21-36.

Balai Taman Nasional. (2015). Buku Statistik Taman Nasional Sebangau Tahun 2014. Kementrian Kehutanan, Direktorat Jenderal Perlindungan Hutan dan Konservasi Alam. Jakarta.

Barbour, G. M., Burk, J. K., \& Pitts, W. D. (1987). Terrestrial Plant Ecology. New York: The Benjamin/Cummings Publishing Company, Inc. pp 157.

Cheyne, S. M., \& Macdonald, D. W. (2011). Wild felid diversity and activity patterns in Sabangau peat-swamp forest, Indonesian Borneo. Oryx, 45(1), 119-124.

Cheyne, S. M., Husson, S. J., Dragiewicz, M., Thompson, L. J., et al. (2014). Kalimantan's tropical peat-swamp forests are important for Storm's Stork (Ciconia stormi) conservation. Journal of Indonesian Natural History, 2(1), 45-50.

Cooper, D. J., Sueltenfuss, J., Oyague, E., Yager, K., et al. (2019a). Drivers of peatland water table dynamics in the central Andes, Bolivia and Peru. Hydrological Processes, 33(13), 1913-1925. https://doi.org/10.1002/hyp.13446.

Cooper, H. V., Vane, C. H., Evers, S., Aplin, P., Girkin, N. T., \& Sjögersten, S. (2019b). From peat swamp forest to oil palm plantations: The stability of tropical peatland carbon. Geoderma, 342, 109-117.

Djufri, D. (2003). Vegetation analysis of spermatophyte in Taman Hutan Raya (Tahura) Seulawah, Aceh Besar. Biodiversitas Journal of Biological Diversity, 4(1), 30-34.

Evans, C. D., Williamson, J. M., Kacaribu, F., Irawan, D., et al. (2019). Rates and spatial variability of peat subsidence in Acacia plantation and forest landscapes in Sumatra, Indonesia. Geoderma, 338, 410-421. https://doi.org/10.1016/j.geoderma.2018.12.028.

Evers, S., Yule, C. M., Padfield, R., O'Reilly, P., \& Varkkey, H. (2017). Keep wetlands wet: the myth of sustainable development of tropical peatlands-implications for policies and management. Global Change Biology,23(2), 534-549. https://doi.org/10.1111/gcb.13422.

Goodman, D. (1975). The theory of diversity-stability relationships in ecology. The Quarterly Review of Biology, 50(3), 237-266. https://doi.org/10.1086/408563.

Gumbricht, T., Roman-Cuesta, R. M., Verchot, L., Herold, M., et al. (2017). An expert system model for mapping tropical wetlands and peatlands reveals South America as the largest contributor. Global change biology,23(9), 3581-3599. https://doi.org/10.1111/gcb.13689.

Gunawan, H., Kobayashi, S., Mizuno, K., \& Kono, Y. (2012). Peat swamp forest types and their regeneration in Giam Siak KecilBukit Batu Biosphere Reserve, Riau, East Sumatra, Indonesia. Mires \& Peat, 10, 1-17.

Hidayat, S. (2014). Kondisi vegetasi di hutan lindung Sesaot, Kabupaten Lombok Barat, Nusa Tenggara Barat, sebagai informasi dasar pengelolaan kawasan. Jurnal Penelitian Kehutanan Wallacea, 3(2), 97-105.

Hooijer, A., Page, S., Jauhiainen, J., Lee, W. A., et al. (2012). Subsidence and carbon loss in drained tropical peatlands. Biogeosciences, 9(3), 1053-1071.doi: 10.5194/bg-9-1053-2012.

Hoscilo, A., Page, S. E., Tansey, K. J., \& Rieley, J. O. (2011). Effect of repeated fires on land-cover change on peatland in southern Central Kalimantan, Indonesia, from 1973 to 2005. International Journal of Wildland Fire, 20(4), 578-588.

Husson, S. J., Limin, S. H., Boyd, N. S., Brousseau, J. J., et al. (2018). Biodiversity of the Sebangau tropical peat swamp forest, Indonesian Borneo. Mires and Peat, 22, 1-50. https://doi.org/10.19189/MaP.2018.OMB.352.

Indriyanto. (2006). Ekologi Hutan. PT BumiAksara. Jakarta. 
Ismaini, L., Lailati, M. \& Rustandi, S. D. (2015). Analisis komposisi dan keanekaragaman tumbuhan di Gunung Dempo, Sumatera Selatan. In Prosiding Seminar Nasional Biodiversitas Indonesia, 1(6), 1397-1402.

Istomo, I., \& Aziz, A. (2021). Struktur Tegakan dan Sebaran Jenis Terentang (Campnosperma auriculata) dan Mendarahan (Knema laurina) di Hutan Rawa Gambut. Jurnal Silvikultur Tropika, 12(1), 9-16.

Joosten, H. (2015). Peatlands, climate change mitigation and biodiversity conservation: An issue brief on the importance of peatlands for carbon and biodiversity conservation and the role of drained peatlands as greenhouse gas emission hotspots ( Vol 2015727). Nordic Council of Ministers.

Kalima, T., \& Denny, D. (2019). Komposisi Jenis dan Struktur Hutan Rawa Gambut Taman Nasional Sebangau Kalimantan Tengah. Jurnal Penelitian Hutan dan Konservasi Alam, 16(1), 51 72. https://doi.org/10.20886/jphka.2019.16.1.51-72.

Kent, M. (2011). Vegetation description and data analysis: a practical approach. John Wiley \& Sons.

Khalwani, K.M., Bahruni, B., \& Syaufina, L. (2017). Nilai Kerugian dan Efektivitas Pencegahan Kebakaran Hutan Gambut (Studi Kasus di Taman Nasional Sebangau Provinsi Kalimantan Tengah). Risalah Kebijakan Pertanian dan Lingkungan: Rumusan Kajian Strategis Bidang Pertanian dan Lingkungan, 2(3), 214-229.

Kimmins, J.P. (1997). Forest Ecology (A Foundation for Sustainable Management). Second Edition. New Jersey (US): Prentice Hall PTR.

Könönen, M., Jauhiainen, J., Laiho, R., Kusin, K., \& Vasander, H (2015). Physical and chemical properties of tropical peat under stabilised land uses. Mires and Peat, 16, 1-13.

Kusmana, C. (1997). Metoda Survey Vegetasi. Penerbit Institut Pertanian Bogor, Bogor.

Kusmana, C., \& Susanti, S. (2015). Komposisi dan struktur tegakan hutan alam di hutan pendidikan Gunung Walat, Sukabumi. Jurnal Silvikultur Tropika, 5(3), 210-217.

Kusnadi, A. (2015). Struktur Komunitas Annelida Sebagai Bioindikator Pencemaran Sungai Ancar Kota Mataram dan Upaya Pembuatan Poster Untuk Pendidikan Masyarakat Tahun 2013. Dalam Prosiding Seminar Nasional Pendidikan Biologi 2015. Malang, Indonesia, 21 Maret 2015 (pp. 1-8).

Loveless, A.R. (1983). Prinsip-prinsip Biologi Tumbuhan untuk Daerah Tropik 2. Gramedia. Jakarta
Magurran, A.E. (2004). Ecological Diversity and Its Measurement. 6th.CroomHelm Ltd.London.

Margalef, R. (1958).Temporal Succession and Spatial Heterogeneity in Phytoplankton. In Buzzati-Traverso A. A (ed), Perspectives in Marine Biology (pp. 323-350). University of California Press. https://doi.org/10.1525/9780520350281-024.

Miettinen, J., Shi, C., \& Liew, S.C. (2016). Land cover distribution in the peatlands of Peninsular Malaysia, Sumatra and Borneo in 2015 with changes since 1990. Global Ecology and Conservation, 6, 67-78. http://dx.doi.org/10.1016/j.gecco.2016.02.004.

Mirmanto, E. (2010).Vegetation analyses of Sebangau peat swamp forest, Central Kalimantan. Biodiversitas, 11(2), 82-88. https://doi.org/10.13057/biodiv/d110206.

Mishra, S., Page, S. E., Cobb, A. R., Lee, J. S. H., et al. (2021). Degradation of Southeast Asian tropical peatlands and integrated strategies for their better management and restoration. Journal of Applied Ecology, 58(7), 1370-1387. https://doi. org/10.1111/13652664.13905.

Mofu, W.Y. (2011).Keanekaragaman Vegetasi dan Biomassa pada beberapa Tipe Penggunaan Lahan Gambut di Kabupaten Kepulauan Meranti Provinsi Riau. PhD Thesis submitted to the Institut Pertanian Bogor, Bogor (ID).

Morrogh-Bernard, H., Husson, S., Page, S.E., \& Rieley, J.O. (2003). Population status of the Bornean orang-utan (Pongo pygmaeus) in the Sebangau peat swamp forest, Central Kalimantan, Indonesia. Biological Conservation, 110, 141- 152.

Nugroho, A.W. (2011). Struktur Vegetasi dan Komposisi Jenis Pada Hutan Rawa Gambut di Resort Habaring Hurung, Taman Nasional Sebangau, Kalimantan Tengah. In Prosiding Seminar Hasil-hasil Peneltian BPTKSDA Hasil-Hasil Riset untuk Mendukung Konservasi yang Bermanfaat dan Pemanfaatan yang Konservatif. (pp. 10). Samboja Kaltim: BPTKSDA.

Odum, E.P. (1993). Dasar-Dasar Ekologi. Gajah MadaPress. Yogyakarta.

Page, S.E., Rieley, J.O., \& Banks, C.J. (2011). Global and regional importance of the tropical peatland carbon pool. Global Change Biology, 17, 798-818. https://doi.org/10.1111/j.13652486.2010.02279.x.

Page, S.E., Rieley, J.O., \& Wüst, R.A.J. (2006). Lowland tropical peatlands of Southeast Asia. In Martini, I.P., Martinez Cortizas, A., \& Chesworth, W. (eds.) Peatlands: Evolution and Records of Environmental and Climate Changes, Developments in Earth Surface Processes (145-172), Elsevier, Amsterdam. 
Page, S.E., Rieley, J.O., Doody, K., Hodgson, S., et al. (1997). Biodiversity of tropical peat swamp forest: A case study of animal diversity in the Sungai Sebangau Catchment of Central Kalimantan, Indonesia. In: Rieley, J.O., \& Page, S.E. (eds.), Biodiversity and Sustainability of Tropical Peatlands (pp, 231242) Samara Publishing Limited, Cardigan, UK.

Page, S.E., Rieley, J.O., Shotyk, W., \& Weiss, D. (1999). Interdependence of peat and vegetation in a tropical peat swamp forest. Philosophical Transactions of the Royal Society of London. Series B, Biological Sciences, 354(1391), 1885-1897.

Päivänen, J.(1973). Hydraulic conductivity and water retention in peat soils. Acta Forestalia Fennica 129, 7563.

Pamoengkas, P., Zamzam, A., \& Dwisutono, A. (2019). Vegetation recovery of logged-over dipterocarp forests in Central Kalimantan, Indonesia. Floresta e Ambiente, $26 \quad$ (3), 1 11.https://doi.org/10.1590/2179-8087.123917.

Parish, F., Sirin, A., Charman, D., Joosten, H., Minaeva, T., \& Silvius, M. (Eds). (2008). Assessment on Peatlands, Biodiversity and Climate Change. Kuala Lumpur, Global Environment Centre, Kuala Lumpur, Malaysia and Wetlands International, Wageningen, The Netherlands. 179 pp.

Posa, M.R.C., Wijedasa, L.S., \& Corlett, R.T. (2011). Biodiversity and conservation of tropical peat swamp forests. BioScience, 61, $49-57$.

Qirom, M.A., Halwany, W., Rahmanadi, D., \& Tampubolon, A.P. (2019). Studi Biofisik pada Lanskap Hutan Rawa Gambut di Taman Nasional Sebangau: Kasus di Resort Mangkok. Jurnal Ilmu Pertanian Indonesia, 24(3), 88-200.

Rydin, H., \& Jeglum, J. (2015). The biology of peatlands.Oxford University Press: Oxford, UK.

Sherwood, J.H., Kettridge, N., Thompson, D.K., Morris, P.J., Silins, U., \&Waddington, J.M. (2013). Effect of drainage and wildfire on peat hydrophysical properties. Hydrological Processes, 27(13), 1866-1874.

Siahaan, S., Manurung, T.F., \& Randi, A. (2014). Identifikasi jenis-jenis pohon penyusun vegetasi gambut taman nasional Danau Sentarum Kabupaten Kapuas Hulu. Jurnal Hutan Lestari, 2(1), 6673. http://dx.doi.org/10.26418/jhl.v2i1.4966.

Sidauruk, N.T. (2016). Struktur danKomposisi Tegakan Tinggaldi Areal Bekas Tebangandi IUPHHK-HA PT. SindoLumber KalimantanTengah. Skripsi. Fakultas PertanianUniversitas PalangkaRaya. PalangkaRaya.
Sidiyasa, K. (2009). Struktur dan komposisi tegakan serta keanekaragaman di hutan lindung Sungai Wain, Balikpapan, Kalimantan Timur. Jurnal Penelitian Hutan dan Konservasi Alam, $6(1), 79-93$.

Silvius, M.J., \& Verheugt, W.J.M. (1986). The birds of Berbak Game Reserve, Jambi Province, Sumatra. Kukila, 2, 76-85.

Simbolon, H. (2004). Proses awal pemulihan hutan gambut Kalampangan-Kalimantan Tengah pascakebakaran hutan Desember 1997 dan September 2002. Berita Biologi, 7(3),145-154.

Sinclair, A.L., Graham, L.L., Putra, E.I., Saharjo, B.H., et al. (2020). Effects of distance from canal and degradation history on peat bulk density in a degraded tropical peatland. Science of The Total Environment, 699, 134199.https://doi.org/10.1016/ j.scitotenv.2019.134199.

Soegianto, A. (1994). Ekologi Kuantitatif: Metode analisis populasi dan komunitas. Usaha Nasional. Surabaya.

Subiandono, E., \& Heriyanto, N.M. (2016). Kajian Tumbuhan Obat Akar Kuning (Arcangelisia flava Merr.) di Kelompok Hutan Gelawan, Kabupaten Kampar, Riau. Buletin Plasma Nutfah, 15(1), 43-48.

Sumarga, E., Hein, L., Hooijer, A., \& Vernimmen, R. (2016). Hydrological and economic effects of oil palm cultivation in Indonesian peatlands. Ecology and Society, 21 (2), 52. https://doi.orgdoi/:10.5751/ES-08490- 210252.

Taman Nasional Sebangau. (2011). Sekilas Tentang TN Sebangau. Balai Taman Nasional Sebangau. Direktorat Jendral Perlindungan Hutan dan Konservasi Alam. Kementerian Kehutanan.

Taman Nasional Sebangau. (2016). Informasi Resort Mangkok SPTN Wilayah II Pulang Pisau. Balai Taman Nasional Sebangau. Palangkaraya.

Tan, Z.D., Lupascu, M., \&Wijedasa, L.S. (2021). Paludiculture as a sustainable land use alternative for tropical peatlands: A review. Science of The Total Environment, 753, 142111, 14 pp. https://doi.org/10.1016/j.scitotenv.2020.142111.

Turetsky, M.R., Benscoter, B., Page, S., Rein, G., Van Der Werf, G.R., \&Watts, A. (2015). Global vulnerability of peatlands to fire and carbon loss. Nature Geoscience, 8(1), 11-14. https://doi.org/10.1038/ngeo2325.

Uda, S.K., Hein, L., \& Sumarga, E. (2017).Towards sustainable management of Indonesian tropical peatlands. Wetlands Ecology and Management, 25(6), 683-701. https://doi.org/10.1007/s11273017-9544-0. 
Wardani, M., \& Susilo, A. (2016). DeskripsiTempatTumbuh, Keragaman Morfologi, dan Kandungan Senyawa Fitokimia Shoreabalangeran Burckdi Hutan Bangka Belitung. Pusat Penelitian dan Penembangan Hutan. Bogor.Indonesia.

Wibisono, I.T.C., Siboro, L., \& Suryadiputra, I.N.M. (2005). Panduan Rehabilitasi dan Teknik Silvikulturdi Lahan Gambut. Proyek Climate Change, Forestand Peatlandsin Indonesia.Wetlands International-Indonesia Programme andWildlifeHabitatCanada. Bogor.

Wichtmann, W., Tanneberger, F., Wichmann, S., \& Joosten, H. (2010). Paludiculture is paludifuture: Climate, biodiversity and economic benefits from agriculture and forestry on rewetted peatland. Peatlands International, $1: 48-51$.

Wijedasa, L.S., Sloan, S., Page, S.E., Clements, G.R., Lupascu, M., \& Evans, T.A. (2018). Carbon emissions from Southeast Asian peatlands will increase despite emission-reduction schemes. Global Change Biology, 24(10), 4598-4613. https://doi.org/10.1111/gcb.14340.

Wildayana, E. (2017). Challenging constraints of livelihoods for farmers in the South Sumatra Peatlands, Indonesia. Bulgarian Journal of Agricultural Science, 23 (6): 894-905.
Wösten, J.H.M., Clymans, E., Page, S.E., Rieley, J.O., \& Limin, S.H. (2008). Peat-water interrelationships in a tropical peatland ecosystem in Southeast Asia. Catena, 73(2): 212-224. https://doi.org/10.1016/j.catena.2007.07.010.

Wösten, J.H.M., Hooijer, A., Siderius, C., Rais, D.S., Idris, A., \& Rieley, J.O. (2006b). Tropical peatland water management modelling of the Air Hitam Laut catchment in Indonesia. International Journal of River Basin Management, 4, 233244. https://doi.org/10.1080/15715124.2006.9635293.

Wösten, J.H.M., Van Den Berg, J., Van Eijk, P., Gevers, G.J.M., et al. (2006a). Interrelationships between hydrology and ecology in fire degraded tropical peat swamp forests. International Journal of Water Resources Development, 22(1):157-174. https://doi.org/ 10.1080/07900620500405973.

Yule, C.M. (2010). Loss of biodiversity and ecosystem functioning in Indo-Malayan peat swamp forests. Biodiversity and Conservation, 19, 393-409. https://doi.org/10.1007/s10531-0089510-5.

Yulianti, R., Marsono, D., \& Yunianto, T. (2009). Analisis Vegetasi Hutan Rawa Gambut Pascakebakaran di Wilayah Desa Sebangau dan Desa Taruna Jaya. Majalah Geografi Indonesia, 24(1), 5-62.

Annexure 1 List of Species Found at the Research Site

\begin{tabular}{|cccc|}
\hline Species & Family & Large Channel & Small Channel \\
\hline Acronychia pedunculata & Pteridaceae & $\sqrt{ }$ & $\sqrt{ }$ \\
\hline Adinandra sp. & Pentaphylacaceae & $\sqrt{ }$ & $\sqrt{ }$ \\
\hline Aglaia rubiginosa & Meliaceae & $\sqrt{ }$ & $\mathrm{X}$ \\
\hline Aglaia sp. & Meliaceae & $\sqrt{ }$ & $\mathrm{X}$ \\
\hline Alseodaphne coriacea & Lauraceae & $\mathrm{X}$ & $\mathrm{X}$ \\
\hline Alstonia spatulata & Apocynaceae & $\sqrt{ }$ \\
\hline Anispotera sp. & Dipterocarpaceae & $\sqrt{ }$ \\
\hline Antidesma coriaceum & Phyllanthaceae & $\sqrt{ }$ & $\mathrm{X}$ \\
\hline Antidesma diandrum & Phyllanthaceae & $\sqrt{ }$ & $\sqrt{ }$ \\
\hline Archidendron borneense & Fabaceae & $\sqrt{ }$ & $\sqrt{ }$ \\
\hline Ardisia sp. & Primulaceae & $\mathrm{X}$ & $\mathrm{X}$ \\
\hline Artabotrys suaveolens & Annonaceae & $\mathrm{X}$ & $\sqrt{ }$ \\
\hline Artocarpus sp. & Moraceae & $\sqrt{ }$ & $\sqrt{ }$ \\
\hline Baccaurea bracteata & Phyllanthaceae & $\sqrt{ }$ \\
\hline Barringtonia longicephala & Meliaceae & $\sqrt{ }$ & $\sqrt{ }$ \\
\hline Beilschmiedia glabra & Lauraceae & $\sqrt{ }$ \\
\hline Blumeodendron kurzii & Euphorbiaceae & \\
\hline Calophyllum inophyllum & $\sqrt{ }$ & \\
\hline
\end{tabular}




\begin{tabular}{|c|c|c|c|}
\hline Species & Family & Large Channel & Small Channel \\
\hline Calophyllum nodusum & Calophyllaceae & $\sqrt{ }$ & $\sqrt{ }$ \\
\hline Calophyllum soullatri & Calophyllaceae & $\sqrt{ }$ & $\sqrt{ }$ \\
\hline Calophyllum sp. 2 & Calophyllaceae & $\sqrt{ }$ & $\sqrt{ }$ \\
\hline Calophyllum sp. 3 & Calophyllaceae & $\sqrt{ }$ & $\sqrt{ }$ \\
\hline Calophyllum sp. 4 & Calophyllaceae & $\sqrt{ }$ & $\sqrt{ }$ \\
\hline Calophyllum venulosum & Calophyllaceae & $\sqrt{ }$ & $\sqrt{ }$ \\
\hline Campnosperma coriaceum & Anacardiaceae & $\sqrt{ }$ & $\sqrt{ }$ \\
\hline Carallia brachiata & Rhizophoraceae & $\sqrt{ }$ & $\mathrm{X}$ \\
\hline Castanopsis tungurrut & Fagaceae & $\mathrm{X}$ & $\sqrt{ }$ \\
\hline Combretocarpus rotundatus & Anisophylleaceae & $\sqrt{ }$ & $\sqrt{ }$ \\
\hline Cratoxylum arborescens & Hypericaceae & $\sqrt{ }$ & $\mathrm{X}$ \\
\hline Crudia tenuipes & Fabaceae & $\sqrt{ }$ & $\mathrm{X}$ \\
\hline Cryptocarya crassinervia & Lauraceae & $\sqrt{ }$ & $\sqrt{ }$ \\
\hline Dacrydium pectinatum & Podocarpaceae & $\sqrt{ }$ & $\mathrm{X}$ \\
\hline Dactylocladus stenostachys & Crypteroniaceae & $\mathrm{X}$ & $\sqrt{ }$ \\
\hline Dialium $\mathrm{sp}$. & Fabaceae & $\sqrt{ }$ & $\sqrt{ }$ \\
\hline Diospyros bantamensis & Ebenaceae & $\sqrt{ }$ & $\sqrt{ }$ \\
\hline Diospyros perfida & Ebenaceae & $\sqrt{ }$ & $\mathrm{X}$ \\
\hline Diospyros pseudomalabarica & Ebenaceae & $\sqrt{ }$ & $\sqrt{ }$ \\
\hline Diospyros siamang & Ebenaceae & $\mathrm{X}$ & $\sqrt{ }$ \\
\hline Diospyros sp. 2 & Ebenaceae & $\mathrm{X}$ & $\sqrt{ }$ \\
\hline Dipterocarpus borneensis & Dipterocarpaceae & $\sqrt{ }$ & $\mathrm{X}$ \\
\hline Dryobalanops beccarii & Dipterocarpaceae & $\sqrt{ }$ & $\mathrm{X}$ \\
\hline Dyera lowii & Apocynaceae & $\sqrt{ }$ & $\sqrt{ }$ \\
\hline Elaeocarpus glaber & Elaeocarpaceae & $\sqrt{ }$ & $\sqrt{ }$ \\
\hline Elaeocarpus mastersii & Elaeocarpaceae & $\sqrt{ }$ & $\sqrt{ }$ \\
\hline Elaeocarpus palembanicus & Elaeocarpaceae & $\mathrm{X}$ & $\sqrt{ }$ \\
\hline Elaeocarpus parvifolius & Elaeocarpaceae & $\sqrt{ }$ & $\sqrt{ }$ \\
\hline Eugenia elmerii & Myrtaceae & $\sqrt{ }$ & $\sqrt{ }$ \\
\hline Evodia speciosa & Rutaceae & $\sqrt{ }$ & $\mathrm{X}$ \\
\hline Fagraea racemosa & Gentianaceae & $\sqrt{ }$ & $\sqrt{ }$ \\
\hline Ficus sp. 1 & Moraceae & $\sqrt{ }$ & $\sqrt{ }$ \\
\hline Ficus sumatrana & Moraceae & $\sqrt{ }$ & $\mathrm{X}$ \\
\hline Garcinia bancana & Guttiferae & $\sqrt{ }$ & $\sqrt{ }$ \\
\hline Gardenia tubifera & Guttiferae & $\sqrt{ }$ & $\sqrt{ }$ \\
\hline Gluta sp. & Anacardiaceae & $\sqrt{ }$ & $\mathrm{X}$ \\
\hline Gnetum cuspidatum & Gnetaceae & $\sqrt{ }$ & $\mathrm{X}$ \\
\hline Gonystylus bancanus & Thymelaeaceae & $\sqrt{ }$ & $\sqrt{ }$ \\
\hline Gymnacranthera farquhariana & Myristicaceae & $\mathrm{X}$ & $\sqrt{ }$ \\
\hline Horsfieldia sp. & Myristicaceae & $\sqrt{ }$ & $\sqrt{ }$ \\
\hline
\end{tabular}

Journal of Experimental Biology and Agricultural Sciences http://www.jebas.org 


\begin{tabular}{|c|c|c|c|}
\hline Species & Family & Large Channel & Small Channel \\
\hline Ilex cymosa & Aquifoliaceae & $\sqrt{ }$ & $\sqrt{ }$ \\
\hline Ilex hypoglauca & Aquifoliaceae & $\sqrt{ }$ & $\mathrm{X}$ \\
\hline Koompassia malaccensis & Fabaceae & $\sqrt{ }$ & $\sqrt{ }$ \\
\hline Lithocarpus conocarpus & Fagaceae & $\sqrt{ }$ & $\sqrt{ }$ \\
\hline Lithocarpus sp. & Fagaceae & $\sqrt{ }$ & $\mathrm{X}$ \\
\hline Litsea lanceolata & Lauraceae & $\mathrm{X}$ & $\sqrt{ }$ \\
\hline Litsea noronhae & Lauraceae & $\sqrt{ }$ & $\sqrt{ }$ \\
\hline Litsea sp. & Lauraceae & $\mathrm{X}$ & $\sqrt{ }$ \\
\hline Litsea sp. 1 & Lauraceae & $\sqrt{ }$ & $\sqrt{ }$ \\
\hline Lophopetalum javanicum & Celastraceae & $\sqrt{ }$ & $X$ \\
\hline Madhuca motleyana & Sapotaceae & $\sqrt{ }$ & $\sqrt{ }$ \\
\hline Mallotus sp. & Euphorbiaceae & $\sqrt{ }$ & $\sqrt{ }$ \\
\hline Mezzettia sp. & Annonaceae & $\sqrt{ }$ & $\sqrt{ }$ \\
\hline Microcos sp. 3 & Malvaceae & $\sqrt{ }$ & $\sqrt{ }$ \\
\hline Myristica maxima & Myristicaceae & $\mathrm{X}$ & $\sqrt{ }$ \\
\hline Myristica sp. & Myristicaceae & $\mathrm{X}$ & $\sqrt{ }$ \\
\hline Neoscortechinia kingii & Euphorbiaceae & $\sqrt{ }$ & $\sqrt{ }$ \\
\hline Nephelium maingayi & Sapindaceae & $\sqrt{ }$ & $\sqrt{ }$ \\
\hline Palaquium ridleyi & Sapotaceae & $\sqrt{ }$ & $\sqrt{ }$ \\
\hline Palaquium sp. 1 & Sapotaceae & $\sqrt{ }$ & $\sqrt{ }$ \\
\hline Palaquium sp. 2 & Sapotaceae & $\sqrt{ }$ & $\sqrt{ }$ \\
\hline Parartocarpus venenosa & Moraceae & $\sqrt{ }$ & $\sqrt{ }$ \\
\hline Platea sp. & Icacinaceae & $X$ & $\sqrt{ }$ \\
\hline Pouteria malaccensis & Sapotaceae & $\sqrt{ }$ & $\sqrt{ }$ \\
\hline Pternandra coerulescens & Melastomataceae & $\mathrm{X}$ & $\sqrt{ }$ \\
\hline Sandoricum beccarianum & Meliaceae & $\sqrt{ }$ & $\sqrt{ }$ \\
\hline Santiria apiculata & Burseraceae & $\sqrt{ }$ & $\sqrt{ }$ \\
\hline Shorea balangeran & Dipterocarpaceae & $\sqrt{ }$ & $\sqrt{ }$ \\
\hline Shorea sp. 2 & Dipterocarpaceae & $\sqrt{ }$ & $\sqrt{ }$ \\
\hline Shorea sp. 3 & Dipterocarpaceae & $\sqrt{ }$ & $X$ \\
\hline Shorea teysmaniana & Dipterocarpaceae & $\mathrm{X}$ & $\sqrt{ }$ \\
\hline Shorea uliginosa & Dipterocarpaceae & $\sqrt{ }$ & $\sqrt{ }$ \\
\hline Stemonurus secundiflorus & Stemonuraceae & $\mathrm{X}$ & $\sqrt{ }$ \\
\hline Sterculia sp. & Malvaceae & $\sqrt{ }$ & $\sqrt{ }$ \\
\hline Syzigium lineatum & Myrtaceae & $\sqrt{ }$ & $\sqrt{ }$ \\
\hline Syzigium sp. 1 & Myrtaceae & $\mathrm{X}$ & $\sqrt{ }$ \\
\hline Syzigium sp. 3 & Myrtaceae & $\sqrt{ }$ & $\sqrt{ }$ \\
\hline Syzygium chloranthum & Myrtaceae & $\sqrt{ }$ & $\sqrt{ }$ \\
\hline Syzygium havilandii & Myrtaceae & $\sqrt{ }$ & $\sqrt{ }$ \\
\hline
\end{tabular}


Effect of Drainage Channels on Vegetation Diversity of Tropical Peat swamp Forest of Sebangau National Park, Indonesia

\begin{tabular}{|c|c|c|c|}
\hline Species & Family & Large Channel & Small Channel \\
\hline Syzygium incarnatum & Myrtaceae & $\mathrm{X}$ & $\sqrt{ }$ \\
\hline Syzygium zeylanicum & Myrtaceae & $\sqrt{ }$ & $\mathrm{X}$ \\
\hline Tarenna fragrans & Rubiaceae & $\sqrt{ }$ & $X$ \\
\hline Tetractomia tetrandra & Rutaceae & $\sqrt{ }$ & $\sqrt{ }$ \\
\hline Tetramerista glabra & Tetrameristicaceae & $\sqrt{ }$ & $\sqrt{ }$ \\
\hline Tristaniopsis merquensis & Myrtaceae & $\sqrt{ }$ & $\sqrt{ }$ \\
\hline Tristaniopsis sp. 2 & Myrtaceae & $\sqrt{ }$ & $\mathrm{X}$ \\
\hline Urophyllum sp. & Rubiaceae & $\sqrt{ }$ & $\mathrm{X}$ \\
\hline Vatica sp. & Dipterocarpaceae & $\sqrt{ }$ & $\sqrt{ }$ \\
\hline Xanthophyllum eurhynchum & Polygalaceae & $\sqrt{ }$ & $\sqrt{ }$ \\
\hline Xanthophyllum stipitatum & Polygalaceae & $\sqrt{ }$ & $\mathrm{X}$ \\
\hline Xerospermum sp. & Sapindaceae & $\sqrt{ }$ & $\sqrt{ }$ \\
\hline Xylopia fusca & Annonaceae & $\sqrt{ }$ & $\sqrt{ }$ \\
\hline
\end{tabular}

Note: $\sqrt{ }=$ Available; $X=$ Not available 